Publisher: Taylor \& Francis

Journal: Expert Opinion on Biological Therapy

DOI: $10.1080 / 14712598.2019 .1561851$

\title{
Bioequivalence studies with anti-TNF biosimilars
}

Authors:

1. Mercedes Gimeno-Gracia

2. Carla J. Gargallo

3. Fernando Gomollón

(1) Service of Pharmacy, Hospital Clínico Universitario "Lozano Blesa", IIS Aragón, Zaragoza Spain

(2) Digestive Diseases Service, Hospital Clínico Universitario "Lozano Blesa", IIS Aragón, CIBEREHD, Zaragoza, Spain.

(3) Departamento de Medicina, Facultad de Medicina. Digestive Diseases Service. Hospital Clínico Universitario "Lozano Blesa"; IIS Aragón; CIBEREHD, Zaragoza, Spain.

Address for correspondence:

Carla J. Gargallo

Department of Gastroenterology, Hospital Clínico Universitario Lozano Blesa.

Avenue San Juan Bosco, nº 15.

50009, Zaragoza. Spain

carlajerusalen@gmail.com

Type of paper: Review (Narrative)

ABSTRACT. 
Introduction: Biosimilars, as defined by the European Medicines Agency, have been used in Europe since 2006. The landscape was considerably expanded when the first biosimilar of a monoclonal was approved and introduced in the European market. CTP13 was developed by Celltrion as an infliximab biosimilar in 2013, not without controversy. As these complex molecules cannot be completely identical, some experts, clinicians, and even patients were skeptical regarding the real bioequivalence of the drugs. Currently, several new infliximab and adalimumab biosimilars are available or will reach the market in a few months

Areas covered: Our goal is to review, mainly from a clinical perspective, the available evidence for bioequivalence of anti-TNF biosimilars. We aim to take into account not only preclinical studies, mostly done for regulatory issues, but also data from clinical studies.

Expert Opinion: We can conclude that bioequivalence with originator is well demonstrated in those drugs which have followed European Medicines Agency regulatory pathways. Switching from originator to biosimilar appears safe for all indications. However, there are few data available for switching from one biosimilar to another, or for complete interchangeability. Prospective studies and strict pharmacovigilance are recommended.

Keywords: infliximab, adalimumab, biosimilar, bioequivalence, switching, anti-TNF. 


\section{INTRODUCTION}

Biological medicines ("biologicals") contain active substances from biological source [1, 2]. The European Medicines Agency (EMA) and the US Food and Drug Administration (FDA) defined a biosimilar medicine as a medicine "highly similar" to another biological medicine already marketed ("reference medicine") in terms of structure, biological activity, clinical efficacy, safety and immunogenicity profile [1,3].

In 2018, a large wave of biosimilar is just starting, and by 2027, 77\% of current biotech spending is expected to be subject to some form of competition. [2]. A large number of biosimilar medicines are in development and can be expected to reach the market in E.U and, may be, the U.S. by 2021 [4]. The introduction of biosimilars increases price competition, which affects not just the price of the respective reference products, but also the price of the whole product class. Price per treatment day (TD) of anti-TNF biosimilars in 2016 compared to price per TD of original products before biosimilar entrance were $-13 \%$. The three European countries where the highest price reduction of the total market were achieved in 2016 were Sweden, Norway and Denmark with $-39 \%,-32 \%$ and $-24 \%$ respectively. Biosimilars have the potential to improve patient access of the total market, for example Sweden has increased volume of anti-TNF in 2016 compared before biosimilar entrance to 74\% and Slovakia intab $93 \%[5]$.

The impact of the introduction of biosimilars for infliximab (IFX) on inflammatory bowel diseases (IBD)-related health care costs has been estimated in the Netherlands. Compared with no introduction of biosimilar, cost savings over a total of 5 years were on average $9,850 €$ per Crohn's disease (CD) patient and 2,250 € per ulcerative colitis (UC) patient [6].

A key point in the clinical development of biosimilars is demonstrating bioequivalence [7]. This review focus on anti-TNF biosimilars and bioequivalence studies to reference product. A systematic review of bioequivalence of anti-TNF biosimilars has been published [8], we add our perspective from a clinical point of view and the evidence emerging in the last two years.

\section{REGULATORY APPROVAL PROCESS}

Biological medicines are made by living organisms, which are naturally variable. Thus, the active substance in the final biological medicine can have an inherent degree of minor variability. This minor variability must fall within the acceptable range to ensure consistent safety and efficacy, and can be present within or between batches of the same biological medicine, particularly when manufacturing processes are modified during the commercial life of 
the medicine [1]. EMA has pioneered in the regulation of biosimilars since the approval of the first one in 2006. The requirements for biosimilar approval in the US by FDA are based on the same scientific rationale as in the EU, although specific data requirements may differ between these two regions due to different legal framework [9]. Other international regulators such as Australia, directly apply the principles set out in the EU legislation [10]. The World Health Organisation (WHO) has developed its own guidelines for biosimilars and biosimilar monoclonal antibodies [11,12], with the aim of providing guidance to regulatory agencies worldwide. These WHO guidelines incorporate many of the scientific principles used by EMA. For this reason this review is going to focus on EU's regulation. Some of our data will not be globally valid, as in some countries regulations are different, and usually less stringent.

Biosimilarity is demonstrated via comparability studies with the reference medicine [7]. Comparability is conceived as a step-wise process that is tailor-made for each product:

- Comparative quality studies: in vitro studies compare the protein structure and biological function using sensitive techniques. These studies should be much more sensitive than clinical trials for detecting such differences.

- Comparative non-clinical studies: these are pharmacodynamics studies in vitro. Pharmacodynamic studies in vivo (animal models) are only done if no suitable in vitro model exists. In vivo toxicological studies are only required in certain cases.

- Comparative clinical studies: these studies are tailored to confirm biosimilarity and to address any questions that may remain form previous analytical or functional studies.

As it has explained before, comparability is not a new concept. In most comparisons with the goal of demonstrating biosimilarity, only detailed analytical and functional in vitro tests are required. However, clinical trials may be needed if any impact on safety and efficacy is anticipated. This is particularly the case with very complex molecules, as monoclonal antibodies, in which is almost impossible to predict all the clinical consequences of a small variation in structure (eg glycosylation).

The goal is to rule out potential product-related differences that could affect pharmacokinetics (PK), efficacy or safety, including immunogenicity. PK studies should be conducted in a homogeneous and sensitive population (healthy volunteers or patients) to detect any possible differences between the biosimilar and its reference medicine. To compare the pharmacological effects, a sensitive endpoint that allows detection of product-specific differences should be chosen. Equivalence margins are set specifically for the indication studied and depend on the endpoint chosen. They should represent the largest difference in efficacy that would not matter 
in clinical practice, treatment differences within this range would thus be acceptable because they have no clinical relevance. These margins are not unique to biosimilar testing, they are routinely used in clinical trials.

In EU, for the marketing authorisation procedure of biosimilar, the applicant should present a risk management plan/pharmacovigilance plan and a postmarketing safety monitoring is also required by FDA $[1,9]$.

\section{INFLIXIMAB AND ITS APPROVED BIOSIMILARS AGENTS}

IFX, marked as Remicade ${ }^{\circledR}$, was the first anti-TNF used for treating IBD. Its biosimilars, CTP13 and SB2, were approved by the EMA and FDA for use across all indications of IFX. Other biosimilar products are in development. Due to the large amount of existing data, we will focus on the preclinical and clinical studies of the two-IFX biosimilars approved by EMA and FDA (CT-P13 and SB2). ( See Table 1)

\subsection{PRECLINICAL EVALUATION OF CT-P13 AND SB2}

$\underline{\text { CT-P13 }}$ has been the first biosimilar agent of IFX and has been the first biosimilar monoclonal antibody evaluated by EMA. CT-P13 has the same amino acid sequence, is produced by the same type of cell line and has an identical pharmaceutical form, composition, route of administration and dosing regimen as the reference IFX. It has demonstrated identical primary and higher order structures than IFX. In terms of charge isoform, it has been observed to contain slightly less basic variants than the original product, the difference was shown to be largely due to the presence of C-terminal lysine, but it has shown no effect on the biological potency or safety of CT-P13 [13].

All major physicochemical characteristics and biological activities of CT-P13 were comparable to those of Remicade ${ }^{\circledR}$. The fermentation, purification of the active substance were adequate. The manufacturing process was satisfactorily validated and quality of the finished product was assured. CT-P13 exhibits a lower level of afucosylated glycans than Remicade ${ }^{\circledR}$, hence a lower binding affinity to FcrRIIIa and a lower binding affinity towards specific Fc receptors and a lower ex vivo in the most sensitive antibody-dependent cellular cytotoxicity (ADCC). However, no difference could be detected in several experiments that are more representative of pathophysiological conditions, and therefore more relevant clinically. All major physicochemical characteristics and biological activities of CT-P13 were comparable to those of Remicade $^{\circledR}$ [14-16]. 
The nonclinical studies CT-P13 versus Remicade ${ }^{\circledR}$ included PD, PK and toxicological studies. The nonclinical data consisted in several in vitro primary PD studies (including a human tissue cross reactivity study comparing biosimilar and original molecule), two pivotal toxicological studies (one with toxicokinetics and immunogenicity testing) and one PK study in order to compare the bioactivity profiles. The comparability was shown in the majority of parameters assessed. Some variability was seen in the results were acceptable, as difference observed in FcrRIIIa binding, this observation does not impact in the biological activity and has no clinically relevant impact of the efficacy and safety of CT-P13 [14,15].

$\underline{\text { SB-2 }}$ is developed and manufactured using Chinese hamster ovary cell (CHO) lines instead of the murine cell line that was used for the production of Remicade ${ }^{\circledR}$. CHO is widely used for the manufacture of biotherapeutics [17,18]. The characterisation of SB-2 included a comprehensive battery of physicochemical and biological tests using sensitive and qualified analytical methods in order to elucidate the primary, secondary, and higher-order structure, post-translational modifications, glycosylation, charge variants, purity/impurities, and quantity and biological properties.

The relative content of C-terminus with Lys for Flixabi ${ }^{\circledR}$ was much lower than that of Remicade $^{\circledR}$, this was explained by the use of $\mathrm{CHO}$ cells. Heterogeneity of C-terminal residues is a characteristic of therapeutic monoclonal antibodies (mAbs), but C-terminal Lys variation does not impact PK profiles and did not impact on TNF- $\alpha$ binding activity [17].

Minor differences were observed in glycosylation pattern (manose and afucose), there was carried out a thorough investigation to support that these changes do not have any clinical relevant impact. The slightly higher FcyRIIb and FcyRIIIa binding Flixabi ${ }^{\circledR}$ compared to Remicade $^{\circledR}$ did not translate into any difference in the relevant biological activity and is therefore concluded to be without impact on safety/efficacy. Additional biological assays were performed to further justify the observed binding difference of FcyRIIIa using various conditions, and to evaluate the in vitro IBD model in order to support extrapolation of indication. The results of the assays indicate that under these conditions the differences are diminished [17].

Terminal sugars of Fc glycans have been shown to be critical for efficacy because Fc glycans influence FcyRIIIa binding and subsequent ADCC activity. Combined percentages of afucosylated and high mannosylated glycans are positively correlated with Fc $\gamma$ RIIIa binding and ADCC in NK92-CD16, while no correlation is observed with the physiologically relevant PBMC (peripheral blood mononuclear cells). Differences in glycosylation could still have some biological impact that might be of interest in later clinical differences [19]. 
Nonclinical studies included a series of in vitro and in vivo studies to demonstrate PD and PK and immunogenic similarities. Similar PK parameters were observed (rat and mice studies). PD studies supported biosimilarity between SB2 and Remicade ${ }^{\circledR}$ as all results were within the similarity range, with the exception of FcyRIIIa (V/V type), FcyRIIb, and FcRn binding assays. However, the difference was within assay variability for Fc $\gamma$ RIIb and FcRn binding assays, and binding activity differences in FcyRIIIa (V/V type) and Fc $\gamma$ RIIb were not translated into ADCC activity since the ADCC activity of SB2 was within the similarity range. FcRn is known to internalise antibodies into cellular endosomes to protect antibodies from proteolysis and thus plays a role in prolonging half-life of serum IgG. Nevertheless, despite the small deviations outside the similarity margin in FcRn binding activity, these were not translated into PK differences $[17,18,20]$.

A higher incidence of anti-drug antibody (ADA) in Flixabi ${ }^{\circledR}$ was found compared to Remicade ${ }^{\circledR}$, so the impact of the differences on the immunogenicity of Flixabi ${ }^{\circledR}$ was discussed in depth. It was concluded that the differences in quality attributes are unlikely to induce higher ADA incidence. Studies showed no differences in epitopes or antibody recognition sites between Flixabi $^{\circledR}$ and Remicade ${ }^{\circledR}[17]$.

\subsection{CLINICAL EVALUATION OF CT-P13 AND SB2}

\section{CT-P13}

Regulatory approval of the IFX biosimilar CT-P13 was based on 2 randomized controlled trials comparing it with its originator product in rheumatic disease: the PLANETAS study in patients with ankylosing spondylitis (AS) [21] and the PLANETRA study in patients with rheumatoid arthritis (RA) [22]. Moreover, PLANETAS and PLANETRA extension studies that evaluate the long-term efficacy and safety of extended CT-P13 treatment over 2 years have recently published [23-25]. See Table 2

The PLANETAS trial, was a phase I randomized, double-blind, parallel-group study that included 250 anti-TNF-naïve patients with active AS [21]. Patients were randomized to receive CT-P13 or IFX dosed at $5 \mathrm{mg} / \mathrm{kg}$ at weeks 0,2 and 6 and then every 8 weeks up to week 30 . The primary endpoint of the trial was to demonstrated PK equivalence at steady state [area under the concentration-time curve (AUC) and observed maximum serum concentration $\left(\mathrm{C}_{\max }\right)$ ] between biosimilar and reference product evaluated between weeks 22 and 30. Steady-state PK was show to be equivalent for CT-P13 and IFX. PLANETAS trial also showed that efficacy, assessed at weeks 14 and 30 and that included several clinical index and clinical criteria, was highly similar between the two groups. The Assessment in Ankylosing Spondylitis Response Criteria (ASAS) 20 and the ASAS40 refer to a $20 \%$ and $40 \%$ improvement, respectively, in a 
set of clinically relevant measures of AS activity. At week 30, the odds ratio (biosimilar/IFX) for the ASAS20 and ASAS40 were 0.91 (95\%CI, 0.51 to 1.62 ) and 1.19 (95\%CI 0.70 to 2.00 ), respectively. Similar findings were obtained at other time points. These efficacy rates were comparable to those reported previously in pivotal trials of IFX in AS. Partial remission rates, adverse events and pharmacokinetics profiles for both products remained equivalent at week 54 . In the subsequent open label PLANETAS extension study $(n=174), 86$ patients treated with IFX were switched to CT-P13 at week 54 and followed for 48 weeks more and 88 patients with CTP13 continued with biosimilar [23]. Efficacy endpoints at weeks 78 and 102 were all of them equivalent between the maintenance and switch groups. The proportion of treatment-emergent adverse events seemed to be slightly higher in patients switching therapy than in patients continuously treated with CT-P13 (71.4\% vs. 48.9\%). However, there were no notable differences between the maintenance and switch groups in the incidence of adverse events leading to treatment discontinuation.

Positive results of PLANETAS trial prompted Celltrion to conduct the PLANETRA trial, a phase III randomized, double-blind, parallel-group study that included patients with active RA despite treatment with methotrexate ( $\geq 3$ months) and received a stable dose (12.5-25 mg/week) for $\geq 4$ weeks before screening [22]. Patients were randomized to CT-P13 ( $n=302)$ or IFX $(n=304)$ with methotrexate and folic acid. The primary endpoint [the American College of Rheumatology 20\% (ARC20) response at week 30] was similar for both groups (60.9\% for CTP13 and $58.6 \%$ for IFX, 95\%CI $-6 \%$ to $10 \%$ ). Other clinical disease activity indices, quality of life and all other PK and pharmacodynamics parameters were also highly similar in both groups. Regarding safety, incidence of drug-related adverse events also were equivalent. Of the 606 patients included in PLANETRA study, 455 (CT-P13:233 and IFX:222) were treated up to week 54. In this week, the ACR 20 response rate (CTP-13 74.7\% vs IFX 71.3\%), remission, pharmacokinetics profile and adverse events rates were also comparable between both groups [24]. Three hundred two patients of 455 who completed the PLANETRA study were enrolled in the open-label, single-arm extension study. All patients received every 8 weeks CT- P13 and concomitant methotrexate from weeks 62 to 102. Of these, 158 had received CT-P13 (maintenance group) and 144 IFX (switch group) previously. At week 102, clinical efficacy and adverse events rate were similar in both groups (maintenance vs switch) [25].

\section{$\underline{\text { SB2 }}$}

Regulatory approval of the biosimilar SB2 was based on two pivotal studies published in 2015 that compared it with Remicade ${ }^{\circledR}$; a phase I randomized, single-blind, three arm, parallel group study in 159 healthy subjects [26] and a phase III, randomised, double-blind, parallel group study in patients with moderate to severe RA despite methotrexate [27]. 
In the phase I study, all patients received a single dose of $5 \mathrm{mg} / \mathrm{kg}$ of one of three IFX study drugs (SB2, EU-IFX or US-IFX) and then were observed for 10 weeks. The primary PK parameters that were studied were AUC from time zero to infinity (AUCinf), AUC from time zero to the last quantifiable concentration (AUClast) and Cmax. Bioequivalence was to be concluded if the $90 \%$ CIs for the ratio of geometric least squares means (LSMeans) of the treatments compared were completely contained within the pre-defined equivalence margin (0.8-1.25). In this clinical study, SB2 showed pharmacokinectic equivalent with its marketed reference products of IFX (EU-IFX and US-IFX). Moreover, no significant difference in terms of safety and immunogenicity profiles was found across the treatment groups [26].

In the phase III study, 584 patients were randomised in a 1:1 ratio to receive SB2 or IFX. In 2017, results of study at week 30 were published [27]. The ACR20 response at week 30 was $64.1 \%$ in SB2 vs. $66.0 \%$ in IFX. The adjusted rate difference was $-1.88 \%$ (95\% CI $-10.26 \%$ to $6.51 \%$ ), which was within the predefined equivalence margin. The adverse event rate was comparable. Also in 2017, study results at week 54 were published [28]. The patient disposition was similar between the both groups: $78.0 \%$ of the SB2 group and $76.8 \%$ of the IFX group completed the 54 week study. We want to note that starting at week 30 , stepwise dose increments by $1.5 \mathrm{mg} / \mathrm{kg}$ up to a maximum of $7.5 \mathrm{mg} / \mathrm{kg}$ were permitted at each visit if RA symptoms were not well controlled by the existing dose. This study showed that SB2 and IFX maintained comparability up to 54 weeks in all efficacy clinical outcomes measured. Indeed, the equivalence margin for the ACR20 rate difference, which was intended for the primary endpoint at week 30, was met also at week 54. In addition, efficacy related to dose increments, whether regarding frequency or final dose, was comparable between SB2 and IFX. The safety profile was comparable up to 54 weeks, with no particular difference from the 30 -week report.

\subsection{EXTRAPOLATION}

In IBD, after a stringent approval process, the EMA and the FDA authorized the CT-P3 and SB 2 by "extrapolation" for all the therapeutic indications for which Remicade ${ }^{\circledR}$ was previously approved, as we mentioned previously.

Extrapolation refers to the process of extending efficacy and safety data derived from one approved therapeutic indication for which the biosimilar has been demonstrated equivalence with reference medicinal product to other indications for which reference product is approved [7]. The approval of a biosimilar requires clinical data, as we mentioned previously, but clinical trials have a relatively minor role compared to their importance in the development and 
approval of new drugs. It is important to know that biosimilar development programs do not want to demonstrate clinical efficacy of the product in a particular clinical indication, since it has been already done with the reference product. An important decision to be taken by de regulatory agencies is if to demand a confirmatory clinical trial for each indication, or to assume that extrapolation of indications is enough guarantee. The EMA state in its most recent published guidelines that "Extrapolation of clinical efficacy and safety data to other indications of the reference monoclonal antibodies is possible based on the overall evidence of comparability provided from the comparability exercise and with adequate justification", but not as an "automatic or systemic conclusion" [29]. In anti-TNF drugs, the EMA has included the mode of action of biosimilar in the "totality of evidence with adequate and relevant justification".

For biological drugs that have several indications, the question arises as to which disease should be targeted in the pivotal clinical trial. The EMA establishes that the most sensitive disease should be selected for increasing the probability to detect any existing difference between products. But it is difficult to define which the most sensitive disease is. In the case of CT-P13, RA was selected for pivotal trial (PLANETRA study) [22], but it has claimed that IFX has a relatively low efficacy vs. placebo effect in this indication. Other aspects that may difficult extrapolation from AS and RA to IBD are lower IFX doses and the concomitant use of methotrexate in the III phase study. Moreover, RA and IBD have different clearance of IFX and different response to other monoclonal antibodies (for example: rituximab is effective in RA but not in IBD), suggesting the possibility of different mechanisms of inflammation.

Despite the stringent approval process performed by regulatory agencies, extrapolation is one of most controversial issues regarding to biosimilars and finds some resistance in medical community [30-32]. Of course, regulatory agencies rules on pharmacovigilance for biosimilars are very strict because of the two trials required to authorise a biosimilar may not be sufficient to detect differences in the safety related to very infrequent adverse events. Because of that, they require a very detailed risk management plan, even more important if extrapolation is approved.

It is interesting to note that recently (2017), Kim Y. H, et al. presented in the $12^{\text {th }}$ Congress of ECCO (European Crohn's and Colitis Organisation), the first phase III randomised, double blind controlled trial that compares CT-P13 with IFX in patients with IBD (active CD) [33]. They showed that the efficacy of CT-P13 was similar to IFX in terms of CD activity index-70 $(\mathrm{CDAI}-70)(\mathrm{p}-\mathrm{value}=0.5613), \mathrm{CDAI}-100(\mathrm{p}-\mathrm{value}=0.7744)$ and clinical remission $(\mathrm{p}-\mathrm{value}=$ $0.8329)$ up to week 6. 


\subsection{IMMUNOGENICITY}

Proteins and other biological medicines have an intrinsic ability to cause an unwanted immune response, which, in rare cases, could cause a serious adverse reaction or reduced efficacy. Formation of immune complexes between antidrug antibody and biologics (reference product and biosimilar) may increase frequency of infusion reactions, increase clearance, reduce serum biologic levels, reduce efficacy, and may have a more direct neutralizing effect on product target binding [32,34-36].

Immunogenicity may be influenced by many factors: product characteristics, treatment-related factors, patient or disease- related factors [32,34]. The proportion of patients who developed treatment-induced ADA varied widely across biologic/biosimilar agents, the incidence of ADA vary considerably across assay methods used and inflammatory disease states [34,36].

FDA mandate at least one clinical trial in which comparative immunogenicity of a biosimilar and its reference product is assessed, EMA has a specific "Guideline on immunogenicity assessment of monoclonal antibodies intended for in vivo clinical use" [9,37].

The frequency of neutralizing ADA has been similar between biosimilars and their reference products [35]. The proportion of patients positive for ADAs at week 54 in PLANETRA study was similar between the two groups: $41.1 \%$ and $36.0 \%$ with CT-P13 and RP, respectively. [24]. On the open label extension of PLANETRA study, switching CT-P13 in patients previously treated with reference product compared to continuing CT-P13 with AR, the proportion of patients with ADAs was similar between both groups at week $102(\mathrm{p}=0.48)$ [25]. See table 3

Immunogenicity was also comparable between SB2 and reference product at 54 weeks [28], $(\mathrm{p}=0,270)$. At week 54 , patients previously receiving IFX were randomised (1:1) to switch to SB2 or continuing SB2, up to week 70 [38], the incidence of ADA was comparable in the different treatments groups. Among patients who were negative for ADA up to week 54, newly developed ADAs were reported in $14.6 \%, 14.9 \%$ and $14.1 \%$ of the INF/SB2, INF/INF and SB2/SB2 groups, respectively. See table 3

Patient who develops antibodies to a reference drug with resultant loss of clinical response should not be switched to its biosimilar. ADAs against IFX and CT-P13 in RA and in IBD patients has been shown equivalent immunogenicity with a similar antigenic profile for both IFX versions [39-41]. Findings in Fiorino's study, in IBD patients, suggest that 
immunodominant epitopes in the reference and CT-P13 drugs are equally present in SB2, all antibodies cross-react with any type of infliximab molecule. CT-P13 and SB2 could be interchangeable and will not lead to differences in ADA production [42].

\subsection{SWITCHING}

Interchangeability and substitution between reference product to biosimilar are an open problem. According to the EMA, interchangeability is to change one medicine for another that is expected to achieve the same clinical result in a given clinical setting and in any patient, with the agreement of the prescribing physician. However, substitution is to dispense one drug instead of another interchangeable drug at pharmacy level, without consulting the prescriber. In general, automatic substitution of biosimilars is not recommended. The FDA determines that a biological product could be considered interchangeable to the referent product only if the biological product is biosimilar and if the expected clinical effects and the safety profile are the same in any given patient and if the risk to switch to biosimilar is not greater than the risk of continue with the originator product [43]. The FDA has the authority to say that a biosimilar is interchangeable and interchangeable product might be substituted for the reference product without the intervention of the prescribing physician [44].

By now, only data regarding switch from infliximab to CT-P13 are available. As we have already mentioned, PLANETAS and PLANETRA extension studies showed similar efficacy and safety after the switch of IFX to CT-P13 and in those who had long-term CT-P13 treatment (102 weeks). Clinical efficacy, safety, and immunogenicity of switching between IFX originator and CT-P13 in IBD were evaluated in several studies [45-70] (see Table 4). Most studies were retrospective, and only one was randomized (NOR-SWITCH trial) [71]. Gisbert et al. [43] in their recent systematic review, and after evaluated 24 studies, showed that disease control was confirmed in 1163 of the 1326 included patients. In the sub-analysis in function of type of the disease, the proportion of patients with $\mathrm{CD}$ that maintained disease control was $86 \%$ and with UC was $93 \%$.

NOR-SWITCH trial deserves special attention, because it is the only controlled and randomized study that evaluates switching [71]. This trial tested the interchangeability from IFX to CT-P13 in patients with different disease: IBD, RA, AS, psoriasic arthritis and chronic plaque psoriasis. Patients included must be on stable treatment with Remicade ${ }^{\circledR}$ for at least 6 months and were randomized 1:1 to either continue IFX or switch to CT-P13. The study was designed as a noninferiority trial (prespecified non-inferiority margin of 15\%). Finally, 481 patients were followed for 52 weeks. The authors did not observe significant increase in disease worsening between originator and biosimilar group. In particular, 155 patients with $\mathrm{CD}$ and 93 with UC 
were included. Disease worsening was reported in $21.2 \%$ vs. $36.5 \%$ in originator and biosimilar CD group and in $9.1 \%$ vs. $11.9 \%$ in originator and CT-P13 UC group. Moreover, there were no differences in safety or immunogenicity. However, this study also has some design limitations and its results cannot yet be generalized to other biologicals medicines and their biosimilars.

Finally, uncertainty remains of multiple switches back-and-forth between a reference medicine and its biosimilar or among multiple biosimilars [72]. We want to note that several ongoing studies will soon provide additional information of the clinical efficacy and safety of switching in patients with IBD (ClinicalTrials.gov :NCT02096861, NCT02998398 and "the SIMILAR Trial"' NCT02452151).

\section{ADALIMUMAB AND ITS APPROVED BIOSIMILARS AGENTS}

There appear to be several "front runners" in the race to biosimilar adalimumab in Europe and United States. Leading the race are biotech major Amgen and Boehringer Ingelheim Pharmaceuticals. Other biosimilar products are in development (table 5). Due to the large amount of existing data we will focus on the preclinical and clinical studies of the two biosimilars of adalimumab approved by EMA and FDA (ABP 501 or BI 695501).

\subsection{PRECLINICAL EVALUATION}

ABP 501 is analytically similar, has the same primary amino acid sequence, similar structure and strength as the reference product. Comparative PD, PK and toxicology data demonstrate biosimilarity between ABP 501 and Humira ${ }^{\circledR}$. [73,74]. A comprehensive assessment between ABP 501, adalimumab (USA) and adalimumab (EU) was conducted to demonstrate similarity in biofunctional activity. This included: testing of binding kinectis to TNF $\alpha$ and relative binding to transmembrane TNF $\alpha$, the neutralizations of TNF $\alpha$-induced caspase activation, TNF $\alpha$ - and lymphotoxin- $\alpha$-induce chemokine production, cytotoxicity, binding to $\mathrm{Fc}$-gamma receptors FcyRIa, Fc $\gamma$ RIIa, Fc $\gamma$ RIIIa and FcRn, antibody-dependent cell-mediated cytotoxicity and complement-dependent cytotoxicity. Data demonstrate that ABP 501 is similar to both adalimumab (US and EU) with respect to biofunctional activities [75].

In a randomised, single-blind, single-dose, three-arm, parallel-group study, healthy subjects were randomised to received ABP 501 ( $\mathrm{n}=67)$, adalimumab (US) ( $\mathrm{n}=69)$ or adalimumab (EU) $(\mathrm{n}=67)$. The confidence interval (CI) for the geometrical mean ratio (GMR) of AUCinf and Cmax were within the prespecified standard PK equivalence criteria of 0,80 to 1.25 [76]. 
BI 695501 has demonstrated to be similar to adalimumab (US and EU). A comprehensive biosimilarity exercise has been performed (analysis of primary sequence, secondary and higher order structure, size, charge and hydrophobicity heterogeneity). Functional activity and antibody clearance was also demonstrated to be similar to adalimumab. The presence of foreign particles detected in some pre-filled syringe lots of BI 695501 was studied in depth, and potential safety issues arising from the presence of particles could be ruled out [77].

In 2016, a randomized, double-blind, active comparator phase I clinical study (VOLTAIRE $^{\circledR}$ PK) in healthy subjects was published. Its aim was to evaluate three-way pharmacokinetic similarity (bioequivalence), safety, and immunogenicity of BI 695501 compared with Humira ${ }^{\circledR}$ in healthy male subjects. Wynne et al. included 327 patients who were randomized 1:1:1 to receive one 40-mg dose of BI 695501, US- or EU-approved Humira ${ }^{\circledR}$. Bioequivalence between the three drugs was demonstrated with the $90 \%$ CIs of the ratios of all primary end points: $\mathrm{C}$ max, AUCinf and AUC from time zero to the last measurable concentration, being within the prespecified acceptance ranges of $80-125 \%$. [78].

A phase II, 7-week, open-label study (VOLAIRTE ${ }^{\circledR}-$ RL) was conducted to examine administration of BI 695501 using autoinjector, showing a successfully self-administration after training [79].

\subsection{CLINICAL EVALUATION OF ABP 501 or BI 695501}

At this time, there is no available clinical data regarding the efficacy of ABP 501 or BI 695501 in IBD. See Table 2.

\section{$\underline{\mathrm{ABP}} 501$.}

Comparable efficacy and safety of ABP-501 to US-Humira ${ }^{\circledR}$ was assessed in 2 randomized, double-blind, phase III equivalence studies in patients with moderate to severe RA and in patients with moderate to severe plaque psoriasis.

- The RA trial consisted of 526 patients treated with either ABP 501 ( $\mathrm{n}=264)$ or USHumira ${ }^{\circledR}(\mathrm{n}=262)$ every 2 weeks with concomitant methotrexate. The primary endpoint, ACR20 response at week 24, safety and immunogenicity were comparable between treatment groups [80].

- In the psoriasis trial was included 350 patients treated with ABP 501 or with originator. 175 patients were randomized to the ABP $501 \mathrm{arm}$. At week 16, half of the reference group was switched to ABP 501 and followed through week 52. Psoriasis Area and Severity Index percent improvements from baseline were similar across groups for weeks 16, 32 and 50 (range: $85 \cdot 8-88 \cdot 2 \%$ ). Changes from baseline in percentage body 
surface area affected were similar across groups and time points. Safety results were also comparable [81]

\section{BI 695501.}

VOLTAIRE-RA study was published in 2018. It is a randomised, double-blind, parallel-arm, 58-week equivalence trial that compared efficacy, safety and immunogenicity of BI 695501 and US-sourced Humira ${ }^{\circledR}$ in patients with moderate-to-severe RA on stable methotrexate treatment. Six hundred forty five patients were randomised 1:1 to receive BI $695501(\mathrm{n}=324)$ or Humira ${ }^{\circledR}$ ( $\mathrm{n}=321) 40 \mathrm{mg}$ subcutaneously for 24 weeks. At week 24, patients originally randomised to Humira ${ }^{\circledR}$ were re-randomised at week 24 to either continue Humira ${ }^{\circledR}(n=148)$ or switch to BI 695501( $\mathrm{n}=147)$. There were no differences in the rate of treatment or trial discontinuation between treatment groups. The difference in the proportion of patients achieving an ACR20 response was within the prespecified interval at week 12 and week 24 demonstrating therapeutic equivalence of both drugs. The analysis of the secondary efficacy endpoints supported the findings of the primary efficacy analysis. The mean percentage of patients meeting the ACR20/50/70 response criteria and the mean change from baseline in DAS28-ESR (Disease Activity Score in 28 joints using erythrocyte sedimentation rate) were similar in each treatment group at weeks 12 and 24 and across the switched and the continuous groups after rerandomisation at week 48. BI 695501 and Humira ${ }^{\circledR}$ demonstrated also similar safety and tolerability [82].

\section{CONCLUSIONS}

Biosimilars are here to stay, and most likely will be very important actors in the fields of rheumatology, dermatology, IBD, ophthalmology and, very specially, oncology. Quality, safety, and efficacy (at least for the clinically tested indications) are clearly warranted for the biosimilars of infliximab (CT-P13 and SB2) and adalimumab (ABP-501 and BI 695501) approved by EMA and FDA.

\section{EXPERT OPINION}

A. Biosimilars to antiTNF biologics approved by EMA and/or FDA have demonstrated bioequivalence in all available studies.

Biologic drugs are complex molecules or even substances. Standard regulations for generics were not adequate, and all regulatory agencies have developed specific rules for approval of biosimilars. EMA pioneered in 2006, and the task was apparently well done, as very few relevant incidents have occurred with different biosimilars in Europe. FDA, Australian, 
Canadian, Japanese, and other regulatory agencies have released very similar regulations. Although when biosimilars to antiTNF antibodies were finally approved some doubts were raised in scientific societies, and patient's associations, educational efforts and growing evidence have shown that EMA rules do a nice work in practice. Controlled and uncontrolled data from clinical trials and registers have shown that EMA biosimilarity nicely translates into clinical biosimilarity.

B. Immunogenicity of biosimilars has not been proven different to originators. In the particular case of CT-P13 immune response to the drug appears identical to originator in a number of very detailed studies

The most controversial issue is that of immunogenicity, because in the case of monoclonal antibodies the extreme complexity of the molecule, very especially in glycosylation, makes theoretically possible a difference in epitopes. This could be particularly important as clinical experience with originators has demonstrated that immunogenicity is a key determinant of secondary failure to these biologic drugs. In the case of CT-P13, the first released biosimilar to infliximab, there have been done very detailed studies with immunological and chemical techniques that have consistently demonstrated a complete immunologic similarity between the two infliximabs: in fact several serologic methods used in clinic for measuring infliximab levels cannot distinguish both molecules. Clinical comparative trials have not shown any difference in immunogenicity between biosimilars and their reference products, and any immunological unexpected side-effect has been appeared when switching from originator to CT-P13. To date, no relevant differences have been shown between biosimilars and their reference products.

C. Switching from originator to biosimilars has been found to be safe and effective in several randomized trials and many prospective, observational studies

Controlled clinical studies are very expensive, and as the differences between originator and biosimilar are expected to be few and difficult to find a high number of subjects needs to be observed to obtain significant statistically and clinically relevant conclusions. However, in all controlled studies biosimilars have shown complete bioequivalence to originators in all cases, according to predetermined criteria. Moreover, a great number of observational studies and data from national or regional registers have confirmed the same type of data. After switching from originator to biosimilar clinical efficacy has not changed and no new safety alert has been detected, in several pathologies and different countries. In fact, thousands of patients have been switched and no consistent problem has been identified to date. 
D. Multiple switching between different biosimilars and originator cannot be recommended with available data

However, it remains the possibility that as new biosimilars are compared to one originator, some differences (may be even important), could exist between two or more biosimilars. Probably, it would be prudent to avoid several changes in the same patient if there is no a very important reason. As more and more molecules reach the market, potential differences could be important. Multiple switching cannot be recommended with available data. We are expecting results from studies with several crossings of drugs in the same group of patients, but no data are available to date. The wealth of data do not suggest that a really clinically significant problem will be detected in the future, but biology is so complex that we should be prudent.

E. No unexpected safety issues have appeared after several years of biosimilars use in areas under reliable and strict regulations

The topic we are considering has very important economic issues. The conflicts of interest can be huge when billions of euros are on the table. This should not be forgotten. So, it is very reassuring for us, as clinicians, that from 2006 the safety record of biosimilars in Europe is excellent. No severe unexpected adverse effect related with a biosimilar has been detected. This record suggests that EMA regulations are very well done, and if pharmacovigilance should remain a priority, we can be confident when prescribing biosimilars to our patients.

\section{F. Personal experience}

In our hospital we have been using several biosimilars from 2006, and soon after release we started using CT-P13 (Inflectra ${ }^{\circledR}$ ) for treating our patients with rheumatologic or digestive indications. In fact, we have direct experience in patients with Ulcerative Colitis and Crohn's disease. We have not been able to see any real difference between the biosimilar and the originator. In fact, we have started all new treatments from 2015 with CT-P13, and we are progressively switching and have not noticed any unexpected problem.

In our opinion, biosimilars approved by EMA are a good alternative for our patients, and do contribute to containing costs for the system. Of course, if we think so one reason is we think bioequivalence has been clearly demonstrated by all methods: quality control, preclinical evaluation, controlled clinical trials, and a substantial quantity of observational data. 


\section{ARTICLE HIGHLIGHTS BOX}

- Biosimilars to antiTNF biologics approved by EMA and/or FDA have demonstrated bioequivalence in all available studies.

- Immunogenicity of biosimilars has not been proven different to originators.

- Switching from originator to biosimilars has been found to be safe and effective in several studies

- Multiple switching between different biosimilars and originator cannot be recommended with available data

- No unexpected safety issues have appeared after several years of biosimilars use

- Biosimilars approved by EMA are a good alternative and do contribute to containing costs for the system

\section{Funding}

This paper was not funded.

\section{Declaration of Interests}

M Gimeno-Gracia has received payments for lectures from Jannsen, Gilead and Roche. CJ Gargallo has received payments for lectures from Takeda and Shire. She has also grant " Juan Rodes" from the Institute Carlos III of Spain. F Gomollon has received payments for lectures from Abbvie, Takeda, and Janssen; and research grants (for the institution) from MSD. The authors have no other relevant affiliations or financial involvement with any organization or entity with a financial interest in or financial conflict with the subject matter or materials discussed in the manuscript apart from those disclosed.

\section{Reviewer Disclosures}

Peer reviewers on this manuscript have no relevant financial relationships or otherwise to disclose.

TABLES

Table 1. Biosimilars and original product of infliximab authorised by EMA and FDA

\begin{tabular}{|l|l|l|}
\hline INFLIXIMAB & EMA & FDA \\
\hline
\end{tabular}




\begin{tabular}{|c|c|c|c|c|c|c|}
\hline & Tradename & Company & $\begin{array}{l}\text { Date of } \\
\text { authorisation }\end{array}$ & Tradename & Company & $\begin{array}{l}\text { Date of } \\
\text { authorisation }\end{array}$ \\
\hline $\begin{array}{l}\text { Original } \\
\text { product }\end{array}$ & Remicade $^{(B)}$ & Janssen & August 1999 & Remicade $^{(\mathbb{R}}$ & Centocor & August 1998 \\
\hline CT-P13 & $\begin{array}{l}\text { Inflectra }^{\circledR} \\
\text { Remsima }^{\circledR}\end{array}$ & $\begin{array}{l}\text { Hospira- } \\
\text { Pfizer } \\
\text { Celltrion }\end{array}$ & $\begin{array}{l}\text { September } \\
2013 \\
\text { September } \\
2013\end{array}$ & Inflectra $^{(B)}$ & Celltrion & April 2016 \\
\hline SB2 & $\begin{array}{l}\text { Flixabi }^{(B)} \\
\text { Zessly }^{\circledR}\end{array}$ & $\begin{array}{l}\text { Samsung } \\
\text { Bioepis } \\
\text { Sandoz }\end{array}$ & $\begin{array}{l}\text { May } 2016 \\
\text { May } 2018\end{array}$ & Renflexis $^{(B)}$ & $\begin{array}{l}\text { Samsung } \\
\text { Bioepis }\end{array}$ & \\
\hline $\begin{array}{l}\text { PF- } \\
06438179\end{array}$ & & & & Ixifi $^{\left({ }^{B}\right.}$ & Pfizer & $\begin{array}{l}\text { December } \\
2017\end{array}$ \\
\hline
\end{tabular}


Table 2: Efficacy of infliximab and adalimumab biosimilar compared with reference products. Randomized controlled trials

\begin{tabular}{|c|c|c|c|c|c|}
\hline \multicolumn{4}{|c|}{ IFX BIOSIMILARS } & \multicolumn{2}{|c|}{ ADALIMUMAB BIOSIMILARS } \\
\hline \multicolumn{4}{|c|}{ CTP13 vs. Reference IFX } & ABP 501 vs. reference a & alimumab \\
\hline $\begin{array}{l}\text { PLANETRA TRIAL (RA) } \\
\text { (ITT population) [25] }\end{array}$ & ACR2O & ACR50 & ACR7O & RA trial [81] & ACR2O \\
\hline $\begin{array}{l}\text { At week } 30 \\
\text { CTP-13 }(n=302) \\
\text { Reference IFX ( } n=304) \\
\text { Tmt difference }(\%)[95 \% \mathrm{Cl}]\end{array}$ & $\begin{array}{c}60.9 \\
58.6 \\
2(-6 \text { to } 10)\end{array}$ & $\begin{array}{c}5.1 \\
34.2 \\
N R\end{array}$ & $\begin{array}{l}16.6 \\
15.5 \\
\text { NR }\end{array}$ & $\begin{array}{l}\text { At week } 24 \\
\text { ABP501 ( } \mathrm{n}=260) \\
\text { Reference adalimumab }(\mathrm{n}=261) \\
\text { RR of ACR20 ( } 90 \% \mathrm{Cl})\end{array}$ & $\begin{array}{c}74.6 \\
72.4 \\
1.04(0.95-1.13)\end{array}$ \\
\hline $\begin{array}{l}\text { At week } 54 \\
\text { CTP-13 }(n=302) \\
\text { Reference IFX }(n=304)\end{array}$ & $\begin{array}{l}57.0 \\
52.0\end{array}$ & $\begin{array}{l}33.1 \\
31.6\end{array}$ & $\begin{array}{l}16.2 \\
15.2\end{array}$ & & \\
\hline PLANETAS TRIAL (AS) $[23,24]$ & ASAS2O & ASAS4O & & Phase II Psoriasis trial [82] & $\begin{array}{c}\text { PASI \% } \\
\text { IMPROVEMENT }\end{array}$ \\
\hline $\begin{array}{l}\text { At week } 14 \\
\text { CTP-13 }(n=115) \\
\text { Reference IFX ( } n=122) \\
\text { OR ( } 95 \% \text { CI) }\end{array}$ & $\begin{array}{c}62.6 \\
64.8 \\
0.91(0.53-1.54) \\
\end{array}$ & $\begin{array}{c}41.7 \\
45.9 \\
0.85(0.51-1.42)\end{array}$ & & $\begin{array}{l}\text { At week } 16 \\
\text { ABP501 ( } n=260) \\
\text { Reference adalimumab }(n=261) \\
\text { least-square mean difference }(95 \% \mathrm{Cl})\end{array}$ & $\begin{array}{c}80.9 \\
83.1 \\
-2.18(-7.39 \text { to } 3.02) \\
\end{array}$ \\
\hline $\begin{array}{l}\text { At week } 30 \\
\text { CTP-13 }(n=112) \\
\text { Reference IFX }(n=116) \\
\text { OR }(95 \% C l)\end{array}$ & $\begin{array}{c}70.5 \\
72.4 \\
0.91(0.51-1.62)\end{array}$ & $\begin{array}{c}51.8 \\
47.4 \\
1.19(0.70-2.00)\end{array}$ & & & \\
\hline $\begin{array}{l}\text { At week } 54 \\
\text { CTP-13 }(n=106)\end{array}$ & 67.0 & 54.7 & & & \\
\hline Reference IFX ( $n=108$ ) & 69.4 & 49.1 & & & \\
\hline
\end{tabular}




\begin{tabular}{|c|c|c|c|c|c|}
\hline OR ( $95 \% \mathrm{Cl})$ & $0.89(0.50-1.59)$ & $1.26(0.73-2.15)$ & & & \\
\hline \multicolumn{4}{|c|}{ SB2 vs. Reference IFX } & \multicolumn{2}{|c|}{ Bl695501 vs. reference adalimumab } \\
\hline $\begin{array}{l}\text { Phase III SB2 (RA) } \\
\text { (Full analysis set) }[27,28]\end{array}$ & ACR2O & ACR50 & ACR70 & $\begin{array}{l}\text { VOLTAIRE -RA trial. RA trial } \\
\text { (Full analysis set) [83] }\end{array}$ & ACR2O \\
\hline $\begin{array}{l}\text { At week } 30 \\
\text { SB2 }(n=290)\end{array}$ & 55.5 & 30.7 & 15.5 & $\begin{array}{l}\text { At week } 12 \\
\text { Bl695501 }(n=321)\end{array}$ & 67.0 \\
\hline Reference IFX ( $n=293$ ) & 59.0 & 33.8 & 17.1 & Reference adalimumab ( $n=318)$ & 61.1 \\
\hline Tmt difference (\%) [95 \% Cl] & $-2.95(-10.8$ to 4.9$)$ & $-2.53(-10.07$ to 5$)$ & $-1.06(-7.06$ to 4.9$)$ & $\begin{array}{l}\text { Difference in proportions } \\
\text { (Bl } 695501 \text { - Humira, \%) } 90 \% \mathrm{Cl}\end{array}$ & $5.9(-0.9$ to 12.7$)$ \\
\hline At week 54 & & & & At week 24 & \\
\hline SB2 $(n=302)$ & 64.5 & 40.8 & 23.2 & $\operatorname{Bl} 695501(n=321)$ & 69.0 \\
\hline Reference IFX ( $n=304)$ & 68.4 & 38.7 & & Reference adalimumab ( $n=318)$ & 64.5 \\
\hline Tmt difference (\%) [95 \% Cl & $-3.34(-11.8$ to 5.1$)$ & NR & & $\begin{array}{l}\text { Difference in proportions } \\
\text { (Bl } 695501 \text { - Humira, \%) } 90 \% \mathrm{Cl}\end{array}$ & $4.5(-3.4$ to 12.5$)$ \\
\hline
\end{tabular}

IFX: infliximab. RA: rheumatoid arthritis. ITT: intention to treat. ACR20: American College of Rheumatology 20\%. ACR50: American College of Rheumatology 50\%. ACR70: American College of Rheumatology 70\%. AS: ankylosing spondylitis. ASAS: Ankylosing Spondylitis Response Criteria. PASI: Psoriasis Area and Severity Index. CI: confidence interval. 
Table 3. Clinical trials evaluating antidrug antibody detected in patients in treatment with infliximab originator and biosimilars CT-P13 and SB2

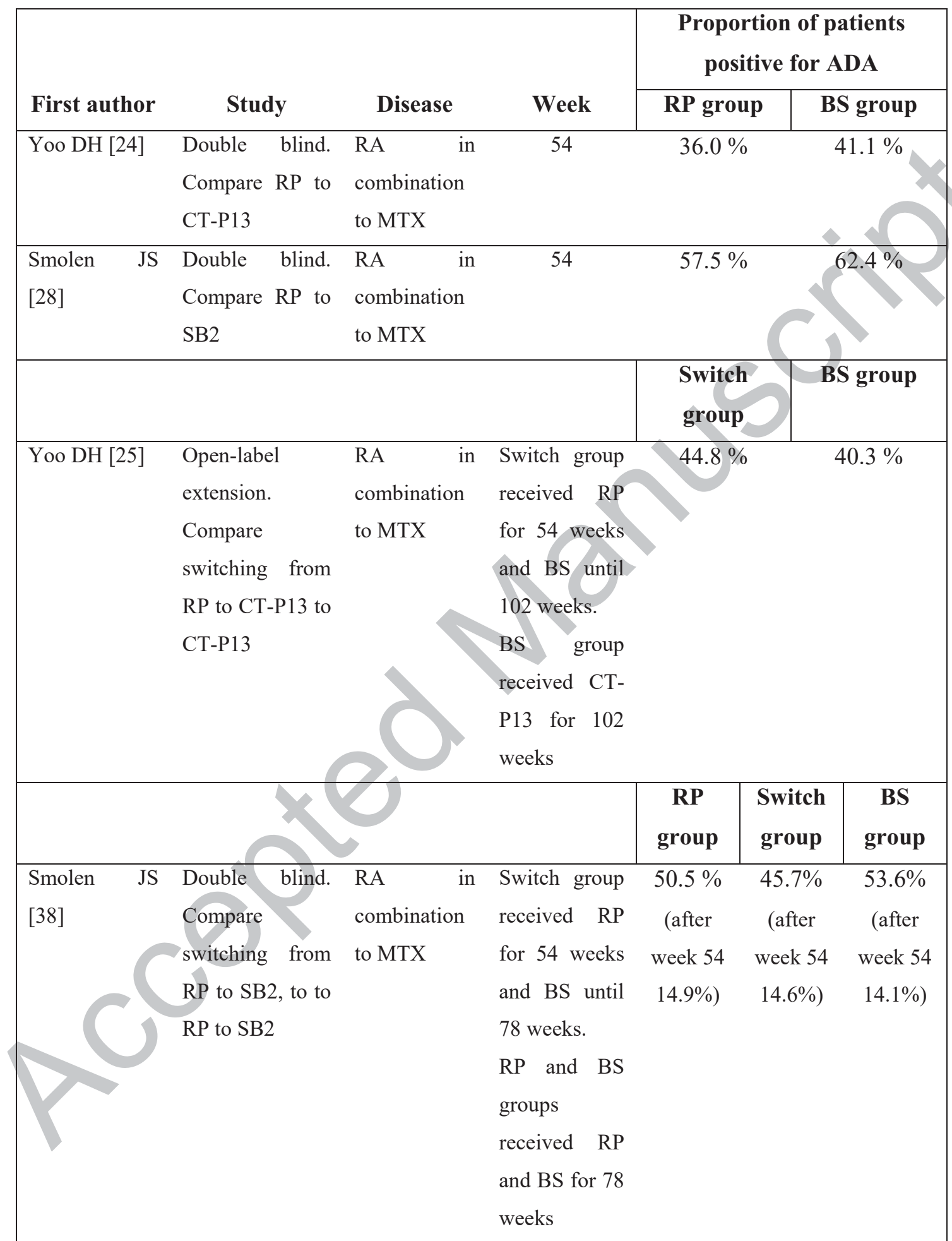

RP: Reference Product; ADA: antidrug antibody; BS: Biosimilar; RA: rheumatoid arthritits; MTX: metotrexate 
Table 4. Studies evaluating switching between infliximab originator and CT-P13.

\begin{tabular}{|c|c|c|c|}
\hline First Author & Study design & $\begin{array}{c}\text { Sample size } \\
\text { ( number of } \\
\text { patients) }\end{array}$ & $\begin{array}{l}\text { Disease Control ( no disease } \\
\text { worsening after switching) }\end{array}$ \\
\hline $\begin{array}{l}\text { Arguelles-Arias } \\
{[45,46]}\end{array}$ & Prospective & 74 & $\begin{array}{l}86 \% \text { at } 6 \text { months } \\
73 \% \text { at } 1 \text { year }\end{array}$ \\
\hline Bettey [47] & Prospective & 134 & $93 \%$ \\
\hline Buer[48] & Prospective & 125 & $95 \%$ \\
\hline $\begin{array}{l}\text { Díaz Hernández and } \\
\text { Rodríguez Glez[49,50] }\end{array}$ & Retrospective & 72 & $\begin{array}{l}100 \% \text { at } 6 \text { months } \\
93 \% \text { at } 1 \text { year }\end{array}$ \\
\hline Eberl [51] & Prospective & 62 & $100 \%$ \\
\hline Fiorino [52] & Prospective & 97 & $100 \%$ \\
\hline Guerrero Puente [53] & Prospective & 36 & $86 \%$ \\
\hline Hamanaka [54] & Retrospective & 3 & $100 \%$ \\
\hline Hlavaty [55] & Retrospective & 12 & $\begin{array}{l}100 \% \text { at } 6 \text { months } \\
75 \% \text { at } 1 \text { year }\end{array}$ \\
\hline Jahnsen [56] & Prospective & 56 & $100 \%$ \\
\hline Jarzebicka [57] & Retrospective & 5 & $100 \%$ \\
\hline Jones [58] & Prospective & 71 & $76 \%$ \\
\hline Jung [59] & Retrospective & 36 & $86 \%$ \\
\hline Kang [60] & Retrospective & 9 & $89 \%$ \\
\hline Kang [61] & Prospective & 27 & $93 \%$ \\
\hline Kolar [62] & Prospective & 74 & $\begin{array}{l}99 \% \text { at } 6 \text { months } \\
100 \% \text { at } 1 \text { year }\end{array}$ \\
\hline Nugent [63] & Prospective & 33 & $85 \%$ \\
\hline Park [64] & Retrospective & 46 & $87 \%$ \\
\hline Razanskaite [65] & Prospective & 143 & $\begin{array}{l}80 \% \text { at } 6 \text { months } \\
73 \% \text { at } 1 \text { year }\end{array}$ \\
\hline Soret [66] & Prospective & 63 & $95 \%$ \\
\hline Sieczkowska [67] & Prospective & 22 & $100 \%$ \\
\hline Smits [68] & Prospective & 51 & $82 \%$ at 4 months \\
\hline Strik [69] & Prospective & 44 & $86 \%$ \\
\hline Suk [70] & Retrospective & 42 & $81 \%$ \\
\hline
\end{tabular}

Table 5 Biosimilars and original product of adalimumab authorised by EMA and FDA 


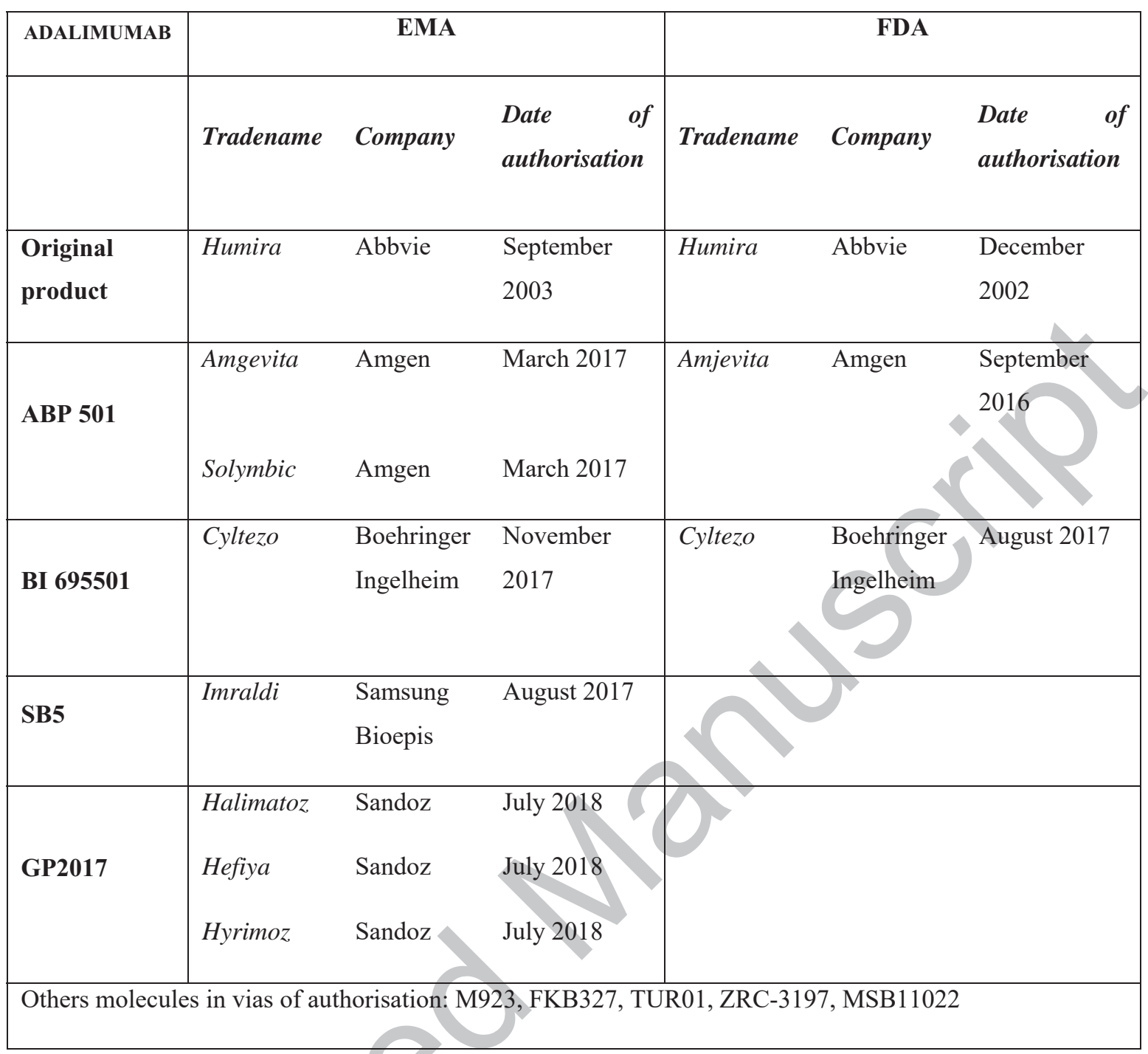

\section{REFERENCES}

Papers of special note have been highlighted as either of interest $(\cdot)$ or of considerable interest $(\bullet)$ to readers. 
1. *European Medicine Agency: Biosimilars in the EU. Information guide for healthcare professionals.

http://www.ema.europa.eu/docs/en_GB/document_library/Leaflet/2017/05/WC500226648. pdf Access on 26 July 2018.

Guide for healthcare professionals about biosimilars: what they are and what scientific principles support their clinical development, approval and safety monitoring.

2. IQVIA Institute for Human Data Science: 2018 and beyond: outlook and turning points. https://www.iqvia.com/institute/reports/2018-and-beyond-outlook-and-turning-points. Access on 26 July 2018.

3. US Food and Administration. Biosimilar and Interchangeable Products. https://www.fda.gov/Drugs/DevelopmentApprovalProcess/HowDrugsareDevelopedandApp roved/ApprovalApplications/TherapeuticBiologicApplications/Biosimilars/ucm580419.htm \#biological. Access on $1^{\text {st }}$ August 2018.

4. IQVIA Institute for Human Data Science: Outlook for global medicines through 2021. Balancing cost and value. https://www.iqvia.com/-/media/iqvia/pdfs/institutereports/global-outlook-for-medicines-through-2021.pdf. Access on 26 July 2018.

5. Quintiles IMS: The impact of biosimilar competition in Europe. https://www.medicinesforeurope.com/wp-content/uploads/2017/05/IMS-Biosimilar2017 V9.pdf. Access on 26 July 2018.

6. *Severs M, Oldenburg B, van Bodegraven AA, Siersema PD, Mangen MJ.J. Initiative of Crohn's and Colitis. The economic impact of the introduction of biosimilars in inflammatory bowel disease. J Crohns Colitis 2017;11:289-96.

Impact on the cost profile of IBD with introduction of infliximab biosimilar, based on Dutch situation

7. Weise M, Bielsky MC, De Smet K, et al. Biosimilars: what clinicians should know. Blood 2012;120:5111-7.

8. *Chingcuanco F, Segal JB, Kim SC, Alexander GC. Bioequivalence of biosimilar tumor necrosis factor- $\alpha$ inhibitors compared with their reference biologics: a systematic review. Ann Intern Med 2016;165:565-74.

Systematic review until April 2016 of bioequivalence between biosimilar and reference anti-TNF $\alpha$

9. US Food and Administration: Scientific consideration in demonstrating biosimilarity to a reference product. Guidance for industry. https:/www.fda.gov/downloads/drugs/guidances/ucm291128.pdf. Access on 26 July 2018.

10. Australian Government. Department of Health Therapeutic Goods Administration. Biosimilar medicines regulation. https://www.tga.gov.au/sites/default/files/biosimilarmedicines-regulation.pdf. Access on 26 August 2018. 
11. World Health Organisation. Guidelines on evaluation of Similar Biotherapeutic Products (SBPs), Annex 2, Technical Report Series. No. 1004, 2016. http://www.who.int/biologicals/publications/trs/areas/biological therapeutics/TRS_977_An nex_2.pdf?ua=1. Access on 26 August 2018.

12. World Health Organisation. Guidelines on evaluation of monoclonal antibodies as Similar Biotherapeutic Products (SBPs), Annex 2, Technical Report Series. No. 977, 2009. http://www.who.int/biologicals/biotherapeutics/WHO TRS 1004_web_Annex_2.pdf?ua=1.

13. Junk SK, Lee KH, Jeon JW, et al. Physicochemical characterization of Remsima ${ }^{\circledR}$. Mabs $2014 ; 6: 1163-77$.

14. European Medicine Agency. Inflectra: EPAR- Public Assessment Report. http://www.ema.europa.eu/docs/en_GB/document_library/EPAR_Public assessment report/human/002778/WC500151490.pdf. Access on $26^{\text {th }}$ July 2018.

15. European Medicine Agency. Remsima: EPAR- Public Assessment Report. http://www.ema.europa.eu/docs/en GB/document library/EPAR Public assessment report/human/002576/WC500151486.pdf. Access on $26^{\text {th }}$ July 2018.

16. Gabani T, Deiana S, Annese V. CT-P13: design, development, and place in therapy. Drug Des Devel Ther 2017;11:1653-61.

17. European Medicine Agency. Flixabi ${ }^{\circledR}$ : EPAR- Public Assessment Report. http://www.ema.europa.eu/docs/en_GB/document_library/EPAR_Public assessment report/human/004020/WC500208358.pdf. Access on $26^{\text {th }}$ July 2018.

18. European Medicine Agency. Zessly ${ }^{\circledR}$ : EPAR- Public Assessment Report. http://www.ema.europa.eu/docs/en GB/document library/EPAR Public assessment report/human/004647/WC500249649.pdf. Access on 26 July 2018.

19. Lee C, Jeong M, Lee JJ, et al. Glycosylation profile and biological activity of Remicade ${ }^{\circledR}$ compared with Flixabi ${ }^{\circledR}$ and Remsima ${ }^{\circledR}$. MAbs 2017;9:968-77.

20. Hong J, Lee Y, Lee C, et al. Physicochemical and biological characterization of SB2, a biosimilar of Remicade ${ }^{\circledR}$. MAbs 2017;9:365-83.

21. **Park W, Hrycaj P, Jeka S, et al. A randomised, double-blind, multicentre, parallel-group, prospective study comparing the pharmacokinetics, safety, and efficacy of CT-P13 and innovator infliximab in patients with ankylosing spondylitis: the PLANETAS study. Ann Rheum Dis 2013;72:1605-12.

Phase I trial that showed pharmacokinetic and pharmacodynamic equivalence between biosimilar CT-P13 and reference product in patients with active ankylosing spondylitis and also an efficacy and safety profile comparable between both products.

22. ** Yoo DH, Hrycaj P, Miranda P, et al. A randomised, double-blind, parallel-group study to demonstrate equivalence in efficacy and safety of CT-P13 compared with innovator 
infliximab when coadministered with methotrexate in patients with active rheumatoid arthritis: the PLANETRA study. Ann Rheum Dis 2013;72:1613-20.

Phase III study that showed equivalence between CT-P13 and reference product in terms of efficacy, immunogenicity, safety and PK-PD in patients with active rheumatoid arthritis not responding adequately to methotrexate.

23. Park W, Yoo DH, Miranda P, et al. Efficacy and safety of switching from reference infliximab to CT-P13 compared with maintenance of CT-P13 in ankylosing spondylitis: 102-week data from the PLANETAS extension study. Ann Rheum Dis 2017;76:346-54.

24. Yoo DH, Racewicz A, Brzezicki J, et al. A phase III randomized study to evaluate the efficacy and safety of CT-P13 compared with reference infliximab in patients with active rheumatoid arthritis: 54-week results from the PLANETRA study. Arthritis Res Ther 2016:2;18:82.

The 54-week findings from phase III study confirm those previously reported at week 30 in PLANETRA study.

25. Yoo DH, Prodanovic N, Jaworski J, et al. Efficacy and safety of CT-P13 (biosimilar infliximab) in patients with rheumatoid arthritis: comparison between switching from reference infliximab to CT-P13 and continuing CT-P13 in the PLANETRA extension study. Ann Rheum Dis 2017;76:355-63.

26. Shin D, Kim Y, Kim YS, Kornicke T, Fuhr R. A Randomized, Phase I Pharmacokinetic Study Comparing SB2 and Infliximab Reference Product $\left(\right.$ Remicade $\left.^{\circledR}\right)$ in Healthy Subjects. BioDrugs 2015;29:381-8.

27. Choe JY, Prodanovic N, Niebrzydowski J, Staykov I, Dokoupilova E, Baranauskaite A, et al. A randomised, double-blind, phase III study comparing SB2, an infliximab biosimilar, to the infliximab reference product Remicade ${ }^{\circledR}$ in patients with moderate to severe rheumatoid arthritis despite methotrexate therapy. Ann Rheum Dis 2017;76:58-64.

28. Smolen JS, Choe JY, Prodanovic N, et al. Comparing biosimilar SB2 with reference infliximab after 54 weeks of a double-blind trial: clinical, structural and safety results. Rheumatology (Oxford). 2017;56:1771-9.

29. European Medicines Agency.Guideline on similar biological medicinal products containing monoclonal antibodies-nonclinical and clinical issues [EMA/CHMP/BMWP/403543/2010]. 2012.

30. Fiorino G, Danese S. The biosimilar road in inflammatory bowel disease: the right way? Best Pract Res Clin Gastroenterol 2014;28:465-71.

31. Danese S, Bonovas S, Peyrin-Biroulet L. Biosimilars in IBD: from theory to practice. Nat Rev Gastroenterol Hepatol 2017;14:22-31.

32. Gargallo CJ, Lué A, Gomollón F. Biosimilars in inflammatory bowel disease. Minerva Med 2017;108:239-54. 
33. Kim Y.H., Ye B.D., Pesegova M et al. Phase III randomised, double-blind, controlled trial to compare biosimilar infliximab (CT-P13) with innovator infliximab in patients with active Crohn's disease: early efficacy and safety results. Paper presented at: 12th Congress of ECCO; 2017; Barcelona, Spain.

34. *Strand V, Balsa A, Al-Saleh J, et al. Immunogenicity of biologics in chronic inflammatory diseases: a systematic review. Biodrugs 2017;31:299-16.

Systematic review to explore the immunogenicity of biologic agents across inflammatory diseases.

35. Bridges SL Jr, White DW, Worthing AB, et al. The science behind biosimilar. Arthritis Rheumatol 2018;70:334-44.

36. Gorovits B, Baltrukonis DJ, Bhattacharya I, et al. Immunoassay methods used in clinical studies for the detection of anti-drug antibodies to adalimumab and infliximab. Clin Exp Immunol 2018;192:348-65.

37. European Medicine Agency: Guideline on immunogenicity assessment of monoclonal antibodies intended for in vivo clinical use. http://www.ema.europa.eu/docs/en_GB/document_library/Scientific_guideline/2012/06/W C500128688.pdf. Access on $3^{\text {rd }}$ August 2018.

38. Smolen JS, Choe J, Prodanovic N, et al. Safety, immunogenicity and efficacy after switching from reference infliximab to biosimilar SB2 compared with continuing reference infliximab and SB2 in patients with rheumatoid arthritis: results of a randomised, doubleblind, phase III transition study. Ann Rheum Dis 2018;77:234-40.

39. Ben-Horin S, Yavzori M, Benhar I, te al. Cross-immunogenicity: antibodies to infliximab in Remicade $^{\circledR}$-treated patiens with IBD similarly recognise the biosimilar Remsima ${ }^{\circledR}$. Gut 2016;65:1132-38.

40. Ruiz-Arguello MB, Maguregui A, Ruiz del Agua A, et al. Antibodies to infliximab in Remicade $^{\circledR}$-treated rheumatic patients show identical reactivity towards biosimilars. Ann Rheum dis 2016;75:1693-6.

41. *Goncalves J, Santos M, Arcurio R, et al. Antigenic response to CT-P13 and infliximab originator in inflammatory bowel disease patients shows similar epitope recognition. Aliment Pharmacol Ther 2018:1-16.

Similar antigenic profile for infliximab originator and CT-P13

42. *Fiorino G, Ruiz-Aguello MB, Maguregui A, et al. Full interchangeability in regard to immunogenicity between the infliximab reference biologic and biosimilars CT-P13 and SB2 in inflammatory bowel disease. Inflamm Bowel Dis 2018;24:601-6.

ADA of Remicade ${ }^{\circledR}$ treated patients, CT-P13 treated patients or Remicade ${ }^{\circledR}$ to CT-P13 switched patients show full cross-reactivity with CT-P13 and SB2. 
43. * Gisbert JP, Chaparro M Switching from an originator anti-TNF to a biosimilar in patients with inflammatory bowel disease: Can it be recommended? A systematic review. Gastroenterol Hepatol 2018;41:389-405.

Critical review on the data evaluating the effectiveness and the safety of switching from reference medicinal products to biosimilars, specifically focusing on the experience of switching between Remicade ${ }^{\circledR}$ and CT-P13 in patients with inflammatory bowel disease.

44. Chow SC. Assessing biosimilarity and interchangeability of biosimilar products. Stat Med 2013;32:361-3.

45. Arguelles-Arias F, Guerra Veloz MF, Perea Amarillo R, et al. Effectiveness and safety of CT-P13 (biosimilar infliximab) inpatients with inflammatory bowel disease in real life at 6 months. Dig Dis Sci. 2017;62:1305-12.

46. Arguelles-Arias F, Guerra Veloz MF, Perea Amarillo R, et al. Switching from reference infliximab to CT-P13 in patients with inflammatory bowel disease: 12 months results. Eur J Gastroenterol Hepatol 2017;29:1290-5.

47. Bettey M, Downey L, Underhill C, et al. Outcomes of a managed switching programme changing IBD patients established on originator infliximab to biosimilar infliximab. J Crohns Colitis 2016;10 Suppl. 1:DOP029.

48. Buer LC, Moum BA, Cvancarova M, et al. Switching from Remicade ${ }^{\circledR}$ to Remsima ${ }^{\circledR}$ is well tolerated and feasible: a prospective, open-label study. J Crohns Colitis 2017;11:297-304.

49. Díaz Hernández L, Rodríguez González GE, Vela González M, et al. Efficacy and safety of switching between originator and biosimilar infliximab in patients with inflammatory bowel disease in practical clinic: results to 6 months. J Crohns Colitis. 2016;10Suppl. 1:P449.

50. Rodríguez Glez GE, Díaz Hernández L, Morales Barrios JA, et al. Efficacy, safety and economic impact of the switch to biosimilar of infliximab in inflammatory bowel disease patients in clinical practice: results of one year. J Crohns Colitis. 2017;11 Suppl.1:P629

51. Eberl A, Huoponen S, Pahikkala T, et al. . Switching maintenance infliximab therapy to biosimilar infliximab in inflammatory bowel disease patients. Scand J Gastroenterol. 2017;24:1-6

52. Fiorino G, Manetti N, Armuzzi A, et al. The PROSIT-BIO Cohort: a prospective observational study of patients with inflammatory bowel disease treated with infliximab biosimilar. Inflamm Bowel Dis. 2017;23:233-43.

53. Guerrero Puente L, Iglesias Flores E, Benitez JM, et al. Evolution after switching to biosimilar infliximab in inflammatory bowel disease patients in clinical remission. Gastroenterol Hepatol 2017;40:595-604

54. Hamanaka S, Nakagawa $\mathrm{T}$, Koseki $\mathrm{H}$, et al. Infliximab biosimilar in the treatment of inflammatory bowel disease: a Japanese single-cohort observational study. J Crohns Colitis 2016;10 Suppl. 1:P329. 
55. Hlavat'y T, Krajcovicova A, Sturdik I, et al. Biosimilar infliximab CT-P13 treatment in patients with inflammatory bowel diseases a one-year, single-centre retrospective study. Gastroenterol Hepatol. 2016;70:27-36.

56. Jahnsen J, Kaasen Jorgensen K. Experience with biosimilar rinfliximab (Remsima ${ }^{\circledR}$ ) in Norway. Dig Dis. 2017;35:83-90.

57. Jarzebicka D, Banaszkiewicz A, Plocek Aet al. Preliminary assessment of efficacy and safety of switching between originator and biosimilar infliximab in paediatric Crohn disease patients. J Crohns Colitis. 2015;10 Suppl. 1:P295

58. Jones ASC, Smith M. Infliximab biosimilar switching program overseen by specialist pharmacist saves money, realises investment and optimises therapy. J Crohns Colitis. 2017;11 Suppl.1:P527.

59. Jung YS, Park DI, Kim YH, et al. Efficacy and safety of CT-P13, a biosimilar of infliximab, inpatients with inflammatory bowel disease: a retrospective multicenter study. $\mathrm{J}$ Gastroenterol Hepatol. 2015;30:1705-12.

60. Kang YS, Moon HH, Lee SE, et al. Clinical experience of the use of CT-P13, a biosimilar to infliximab in patients with inflammatory bowel disease: a case series. Dig Dis Sci 2015;60:951-6.

61. Kang B, Lee K, Choe YH. Long-term outcomes after switching from originator infliximab to biosimilar in paediatric-onset inflammatory bowel disease patients: a single centre prospective observational study. Crohns Colitis. 2017;11 Suppl. 1:P542.

62. Kolar M, Duricova D, Bortlik M, et al. Infliximab biosimilar $\left(\right.$ Remsima $\left.^{\circledR}\right)$ in therapy of inflammatory bowel diseases patients: experience from one tertiary inflammatory bowel diseases centre. Dig Dis. 2017;35:91-100.

63. Nugent S, Nugent M, Mullane D, et alC. EirSwitch echoes of NorSwitch: switching biosimilar therapy in an IBD cohort an Irish experience. Crohns Colitis. 2017;11 Suppl. 1:P430.

64. Park SH, Kim YH, Lee JH, et al.Post-marketing study of biosimilar infliximab (CT-P13) to evaluate its safety and efficacy in Korea. Expert Rev Gastroenterol Hepatol. 2015;9 Suppl. $1: 35-44$.

65. Razanskaite V, Bettey M, Downey L, et al. Biosimilar infliximab in inflammatory bowel disease:outcomes of a managed switching programme. J Crohns Colitis 2017;11:690-6.

66. Soret PA, Prieux-Klotz C, Avouac J. et al. Efficacy and safety of switching from reference infliximab to biosimilar infliximab in patients with inflammatory bowel disease: first French experience. J Crohns Colitis.2017;11 Suppl. 1:P471

67. Sieczkowska J, Jarzebicka D, Banaszkiewicz A. et al. Switching between infliximab originator and biosimilar in paediatric patients with inflammatory bowel disease, preliminary observations. J Crohns Colitis. 2016;10:127-32. 
68. Smits LJ, Derikx LA, de Jong DJ, et al. Clinical outcomes following a switch from Remicade $^{\circledR}$ to the biosimilar CT-P13 in inflammatory bowel disease patients: a prospective observational cohort study. J Crohns Colitis. 2016;10:1287-93.

69. Strik A, van de Vrie V, van Megen Y, et al. Unchanged infliximab serum concentrations after switching from the reference infliximab to the biosimilar CT-P13 in patients with quiescent Crohn's disease: a prospective study. J Crohns Colitis. 2017;11 Suppl. 1:P665.

70. Suk YJ, Park DY, Kim YH, et al. Efficacy and safety of infliximab's biosimilar (Remsima $^{\circledR}$ ) for IBD. J Crohns Colitis. 2015;10 Suppl. 1:P540.63

71. ** Jorgensen KK, Olsen IC, Goll GL, et al. Switching from originator infliximab to biosimilar CT-P13 compared with maintained treatment with originator infliximab (NORSWITCH): a 52-week, randomised, double-blind, non-inferiority trial. Lancet. 2017;389:2304-16.

The only controlled and randomized study that evaluates switching and shows that switching from infliximab originator to CT-P13 was not inferior to continued treatment with infliximab originator. The study was not powered to show non-inferiority in individual diseases

72. Kay J, Winthrop KL. Pharmacotherapy: Biosimilar switching-“To set a form upon desired change". Nat Rev Rheumatol 2017;13:391-2.

73. EMA. Amgevita: EPAR Public assessment report. http://www.ema.europa.eu/docs/en_GB/document_library/EPAR_Public assessment report/human/004212/WC500225277.pdf. Acces on 26 $6^{\text {th }}$ July 2018.

74. FDA. Drug approval package: Amjevita (adalimumab-atto). Medical review. https://www.accessdata.fda.gov/drugsatfda_docs/nda/2016/761024Orig1s000MedR.pdf. Acces on $2^{\text {nd }}$ August 2018.

75. Velayudhan J, Chen Y, et al. Demonstration of functional similarity of proposed biosimilar ABP 501 to adalimumab. Biodrugs 2016;30:339-51.

76. Kaur P, Chow V, Zhang N, Moxness M, Kaliyaperumal A, Markus R. A randomised, single-blind, single-dose, three-arm, parallel-group study in healthy subjects to demonstrate pharmacokinetic equivalence of ABP 501 and adalimumab. Ann Rheum Dis 2017;76:52633.

77. EMA. Cyltezo: EPAR - Public assessment report. http://www.ema.europa.eu/docs/en_GB/document library/EPAR Public assessment_report/human/004319/WC500238609.pdf. Acces on $2^{\text {nd }}$ August 2018.

78. Wynne C, Altendorfer M, Sonderegger I et al. Bioequivalence, safety and immunogenicity of BI 695501, an adalimumab biosimilar candidate, compared with the reference biologic in a randomized, double-blind, active comparator phase I clinical study (VOLTAIRE®-PK) in healthy subjects. Expert Opin Investig Drugs. 2016;25:1361-70. 
79. Cohen S, Klimiuk PA, Assudani D. Successful administration of BI 695501, an adalimumab biosimilar, using an autoinjector (AI): results form Phase II open-labell clinical study (VOLTAIRE $^{\circledR}$-RL). Exper Opin Drug Deliv 2018;15:545-48.

80. *Cohen S, Genovese MC, Choy E' et al. Efficacy and safety of the biosimilar ABP 501 compared with adalimumab in patients with moderate to severe rheumatoid arthritis: a randomised, double-blind, phase III equivalence study. Ann Rheum Dis. 2017;76:1679-87. Phase III equivalence study that showed comparable efficacy, safety and immunogenicity between ABP 501 and US-Humira ${ }^{\circledR}$ in patients with active rheumatoid arthritis on stable methotrexate treatment

81. Papp K, Bachelez H, Costanzo A Clinical similarity of biosimilar ABP 501 to adalimumab in the treatment of patients with moderate to severe plaque psoriasis: A randomized, doubleblind, multicenter, phase III study. J Am Acad Dermatol. 2017;76:1093-102.

82. *Cohen SB, Alonso-Ruiz A, Klimiuk PA, et al. Similar efficacy, safety and immunogenicity of adalimumab biosimilar BI 695501 and Humira reference product in patients with moderately to severely active rheumatoid arthritis: results from the phase III randomised VOLTAIRE-RA equivalence study. Ann Rheum Dis. 2018;77:914-21.

Phase III study that showed comparable efficacy, safety and immunogenicity between BI 695501 and US-sourced Humira ${ }^{\circledR}$ in patients with active rheumatoid arthritis on stable methotrexate treatment 